ISSN 2080-1653

Dol 10.24917/20801653.322.20

\author{
ŁUKASZ GAWOR \\ Silesian University of Technology, Gliwice, Poland \\ PIOTR DOLNICKI \\ Pedagogical University of Cracow, Poland
}

\title{
Arctic Tourism Development with Regard to Legal Regulations and Environmental Protection
}

\begin{abstract}
Arctic tourism develops very quickly and requires both changing of legal regulations and considering environmental issues. The developing branch of services (significantly tourism) has became an important sector in the shaping of the budget of numerous countries worldwide. World-wide climate changes provide new possibilities of visiting remote countries with severe climate conditions. Global warming is particularly intense in the Arctic, where mean temperatures have recently risen twice as fast as in the rest of the world. A comprehensive set of regulations was recently developed to protect the wilderness of Arctic environment from the negative impact of tourism. The purpose of the paper is to present legal and organizational regulations connected with organization of tourist trips in the Arctic, based on the example of Svalbard area, American Arctic and Russian Arctic. There are described particularly legal regulations that concern cruise operators. These issues have been described based on literature studies, analysis of legal regulations and statistical data. The time range of the study is about 20 years. Also discussed are challenges of tourism as seen in the Northwest Passage, a historical challenge for many sailors and Russian Arctic tourism development. The issues of economic benefits, environmental protection and connections between tourism and climate conditions are presented. There is also a focus on weather enabling tourism in the Arctic. It can be said that new possibilities of visiting remote places with severe climate conditions (e.g. Arctic region) are opening due to global changes. It occurs mainly due to the reduced sea ice cover for longer periods of time, which facilitates tourist access and extends visitor seasons. It has been assumed that global climate change may lead to a shift of tourism demand to higher latitudes, creating additional opportunities for tourism in northern regions.
\end{abstract}

Keywords: arctic tourism; environmental protection; global changes; legal regulations

Received: 5 December 2017

Accepted: 20 May 2018

\section{Suggested citation:}

Gawor, Ł., Dolnicki, P. (2018). Arctic Tourism Development with Regard to Legal Regulations and Environmental Protection. Prace Komisji Geografii Przemysłu Polskiego Towarzystwa Geograficznego [Studies of the Industrial Geography Commission of the Polish Geographical Society], 32(2), 289-298. https://doi.org/ $10.24917 / 20801653.322 .20$ 


\section{INTRODUCTION}

The significance of the Arctic tourism is growing yearly. New possibilities of visiting remote places with severe climate conditions are opening due to global changes. World-wide warming of the climate is particularly intense in the Arctic, where mean temperatures have recently risen twice as fast as in the rest of the world (Snyder 2007). Reduced sea ice cover for longer periods of time facilitates tourist access and extends visitor seasons. Satellite data since 1978 show that the annual average Arctic sea ice extent has decreased by $2.7 \%$ per decade, with larger decrease of $7.4 \%$ per decade in summer (www.ipcc.ch). It enables particularly cruise tourists to discover high latitude regions.

The aim of the article is to show the organizational requirements for tourism in the Arctic, including legal regulations, to describe challenges of tourism in polar regions based on the example of three Arctic regions (Svalbard area, American Arctic, and Russian Arctic) and discussing the issues of environmental protection and connections between tourism and climate conditions.

These issues have been described based on literature studies, analysis of legal regulations and statistical data. The time range of the study is about 20 years.

\section{SIGNIFICANCE OF TOURISM FOR ECONOMICS}

Tourism has become a very important sector in the shaping of the budget of numerous countries worldwide. A classic interpretation of the term "tourism" was proposed by W. Hunziker and describes tourism as "the sum of the phenomena and relationships arising from the travel and stay of non-residents, insofar as they do not lead to permanent residence and are not connected with any earning activity" (Hunziker and Krapf, 1942, after Panasiuk, 2006). Definition in the literature is consistent with the standpoint worked out during International Conference of Statistic in Tourism organized by WTO in Ottawa in 1991, which defines tourism as "the activities of persons travelling to and staying in places outside their usual environment for not more than one consecutive year for leisure, business and other purposes" (www.world-tourism.org). A clearer definition can be found at the British Tourism Society, which in 1979 adopted a definition based upon the work of Burkart and Medlik (1974): "Tourism is deemed to include any activity concerned with the temporary short-term movement of people to destinations outside the places where they normally live and work, and their activities during the stay at these destinations" (Burkart and Medlik, 1974).

Tourism branch comprises not only important component of international service sector but also stimulates using new terrains as new "product" which enables to reinforce competiveness of tourist companies and local region. It is also a cognitive impulse stimulating demand for visiting these places.

Undoubtedly one of such regions is the Arctic, which is still identified with inaccessible and mysterious places of the globe and tourist traffic, which in fact has existed for years, but is relatively low in comparison with other tourist regions of the world. This region ensures a direct meeting with nature which is a basis of natural part of tourist product.

The Arctic referring to tourist terminology presents high resistance of the natural environment, where the following should be mentioned: adaptation for relations with nature and barrier with regard to the distance, as well as to the non-developed 
environment. The limits are connected also with logistic problems, which may be eliminated in connection to the investors' interest. A more serious problem is the concern about protection of unique ecosystems, which in the period of global climate changes are dynamically transforming. Weather and climate belong to the most important tourist values and they are the factors of popularity of the region. as well as risk factors.

\section{THE INFLUENCE OF GLOBAL CHANGES ON TOURISM INDUSTRY}

Observed climate changes inspire predictable scenarios, which determine the increase of air temperature of $2.5-4.0{ }^{\circ} \mathrm{C}$ in winter and $1-3{ }^{\circ} \mathrm{C}$ in summer (www.ipcc.ch; www. acia.uaf.edu/pages/scientific.html). The Arctic is a region particularly sensitive to global changes in the climate Since the half of the 1970s warming of the European part of the Arctic has significantly risen. R. Przybylak (2002) counted that the trend of the increase of air temperature induces for attempts of determining of symptoms of climate changes which have influence on different components of environment and are impulse for discussion on changes of climate conditions for tourism (Przybylak, 2002). Climate affects the length of tourist season, behaviours of inhabitants and tourists. Climate determines technologies, infrastructure and characteristics of base and development of tourist space. Climate imposes production of particular goods and applying in tourist traffic service proper facilities and equipment.

It is obvious that the organization of tourism looks different in non-glaciated areas in periglacial regions, which create new geotourist attractions. The melting of ice cover results in emergence of new glacial landforms at the glacier forefields; definite relief of frost wedge polygons etc. creates possibilities of showing new, natural tourist attractions (photo. 1).

Photo 1. Werenskiold Glacier's forefield as a geotourist attraction

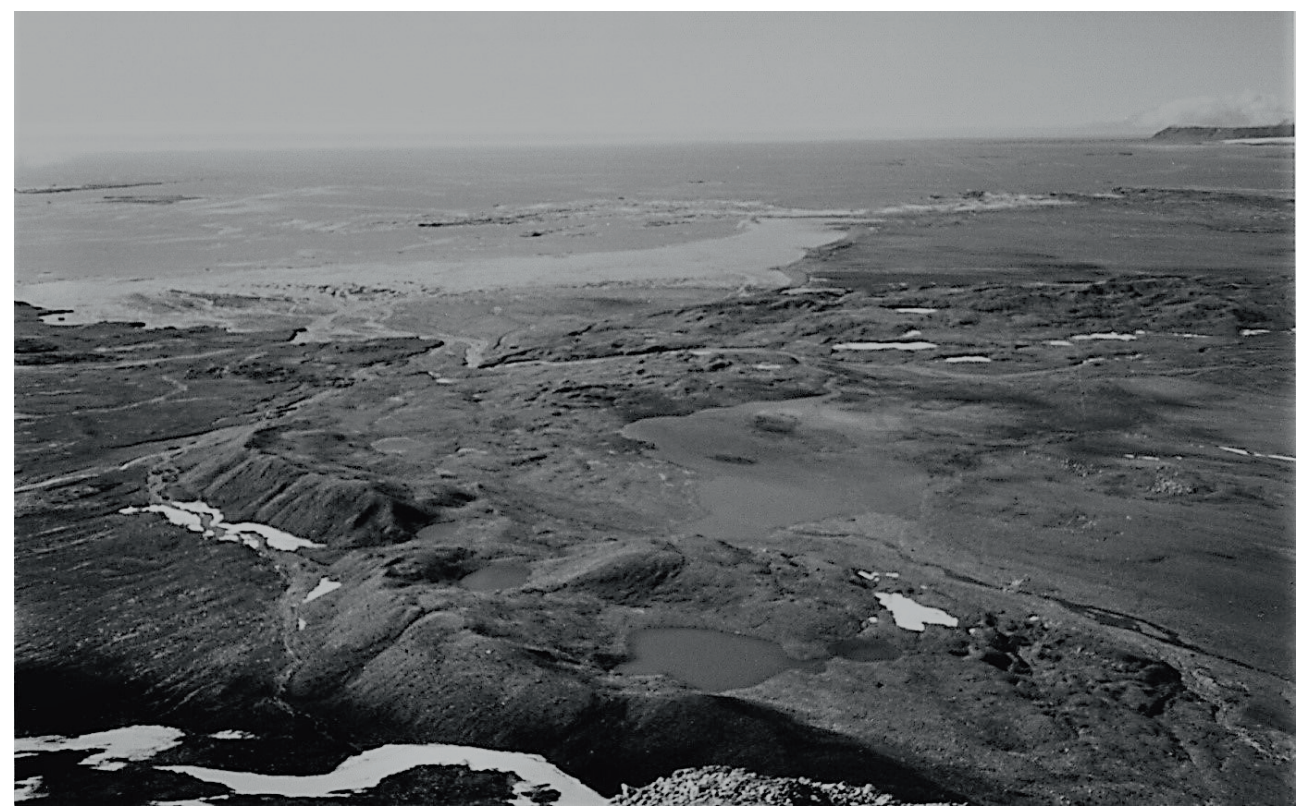

Photo: Ł. Gawor 
The occurrence, as well as changing time of maximal accumulation and total ablation of snow cover change time of scooter or ski exploration of Arctic regions. Higher and higher rise of sea level accompanied by concurrent shrinking of ice-cover, lead to larger damage caused by increasing shore erosion, but also enables new communication solutions. Increasing number of communication trails and accommodation facilities is a general factor stimulating development of tourism in studied area (photo. 2).

Till now only few representatives of tourism branch realize direct dependence between depletion of natural resources of particular region and impoverishment of its touristic values. It is often said that tourism destroys environmental components, among them also indirectly climate. Especially transport and energy-consuming technologies (heating, ventilation) applied in tourist objects cause the increase of emissions of Greenhouse gases. The UN, during an international meeting in Davos warned the whole tourist branch of negative results of climatic changes. What is more, the UN institutions say that it is world tourism that contributes to negative consequences of climate changes. As World Trade Organization reports, in 2013 there were 842 million journeys all over the world and in 2020 this number can reach 1.5 billion. It is exactly transport, accommodation and other factors connected with tourism that are responsible for $4-6 \%$ of world pollution. Tourism is more and more often reproved for its negative influence on the environment, but it is important to give these opinions in categories of sustainable development. The paradox depends upon the fact that tourism is concurrently "guilty" and "a sufferer". Tourism activities cause damage which directly threats regions of tourist penetration and, on the other hand, tourism is also a "victim" of consequences of degradation of the environment, which diminishes attractiveness and, in consequence, incomes obtained from recreation and travelling. This strict evaluation of tourism did not concern relations between tourism and global climate changes.

Photo 2. New houses and communication networks in Logyearbyen, Svalbard

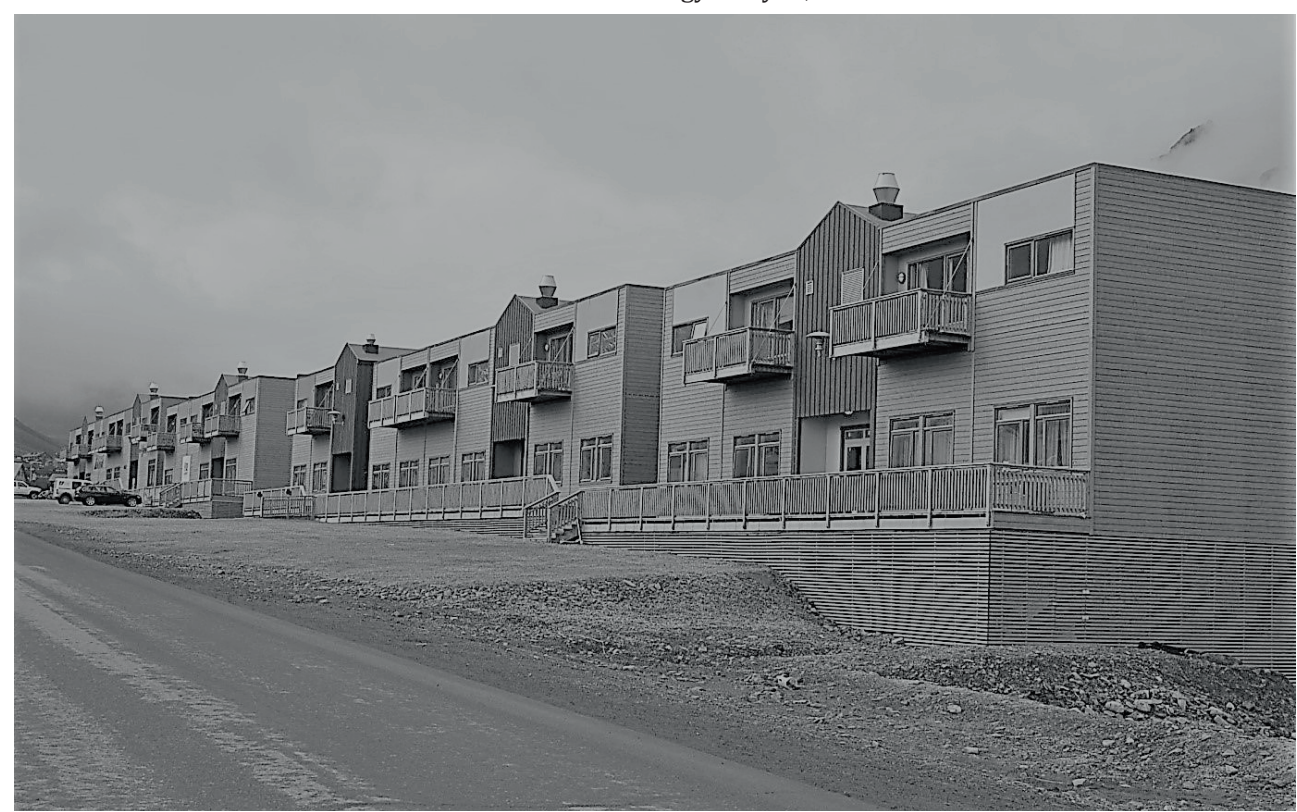

Photo: Ł. Gawor 
Another conferences organized by WTO have taken thematic scope of relations between development of tourism and climate changes. The first meeting in Djerba, Tunisia in 2003 has induced long discussions (Pagnan, 2003). The second conference took place in Davos-Bali in 2007 and ended with a declaration of taking regular activities towards common action of propagation of qualified tourism and mass tourism in harmony with the environment. Another meetings (Copenhagen, 2009; Cancun, 2010; Durban, 2011; Doha, 2012) were a consequence of Davos Declaration. The legal systems of particular Arctic countries take into consideration these statements in tourism traffic regulations. Nowadays it is common to speak about sustainable development in tourism, which imposes the necessity of applying environmental protection strategies including climate (www.wto.org).

\section{DYNAMICS OF TOURISM IN THE ARCTIC}

Nowadays European Arctic is the best developed market with a majority of visitors concentrating in this area, which covers Scandinavia, Svalbard, Greenland, Iceland and Faroe Islands. Most visitors are reported on the continent (e.g. Norway, Sweden, Finland). In the year 2013 in Svalbard there were 107,000 visitors reported, 81,000 in Greenland and around 112,000 tourists visited Faroe Islands (Bystrowska, Dolnicki, 2015).

As far as the American Arctic is concerned, Alaska holds the record in cruise traffic numbers. The biggest growth occurred there between 1997 and 2008 - from 500,000 to more than $1,000,0000$ tourists. During the summer season of 2014, Alaska was visited by around 1,660,0000 tourists, with around 1,000,000 on boards of ships (www.commerce.alaska.gov).

The Russian Arctic has been only recently opening to tourists, among others, by improving routes and cross-border cooperation mainly in the Barents region. The number of tourists is presented on the example on the Russian Arctic National Park area. In the first season (2008), there were 11 cruises reported in the park with 865 tourists. In 2012 there were 1,005 visitors, 636 in 2014 and 738 in 2014 (www.aeco.no).

\section{CASE STUDiES}

One of the best examples of described processes may be Northwest Passage, a historical challenge for many sailors. The other example can be Russian Arctic tourism development, which shows a combination of economic and environmental conditions. Both examples are presented below as case studies.

\section{Northwest Passage case study}

In 1906 Roald Amundsen successfully traversed the Northwest Passage. In 1944 a Royal Canadian Mounted Police sergeant Henry A. Larsen made the first single-season crossing of the Northwest Passage. Since then, many ships have made the trip through the Northwest Passage (Rosenberg, 2007).

The first cruise ship successfully crossed the Northwest Passage in 1984. Sailing the Northwest Passage in private yachts took off in the 2000s. As the Northwest Passage becomes increasingly ice-free during summer, a significant upswing in tourists arriving by sea can be noticed (Wallace, 2006). For the last five years, the passage has 
been nearly ice-free in the late summer, according to Environment Canada data (http:// climate.weather.gc.ca). An ice-free and navigable Northwest Passage not only opens up the possibility of trade routes but also environmental and cultural destruction in the delicate Arctic ecosystem (Wallace, 2006). Nowadays cruises are the basis of tourism in the Arctic Canada. These are only expedition cruises up to 100-300 passengers and private vessels, so tourism numbers in the area are relatively small, however they are expected to grow in the near future (Stewart et al. 2013; Bystrowska, Dolnicki, 2015).

\section{Russian Arctic case study}

Russia is the single largest Arctic land. The Russian sector of Europe may be subdivided into two main groups: coasts of the Barents and the White Seas, as well as high-latitude archipelagos. Cruises to Franz Josef Land and the Novaya Zemlya islands may include even a visit to the North Pole on nuclear icebreakers (e.g. Yamal) or helicopters (sometimes - with last kilometres on skies). These areas have no permanent population. Infrastructure there is completely absent or undeveloped (http://www.biodiversity.ru/ coastlearn/tourism-eng/casestudies_arctic.html).

The Russian Government has allocated RUB 23.4 million to the establishment of a state institution called "Russian Arctic National Park". This institution will create conditions for regulated tourism in the Arctic. The national park covers the northern territory of the Novaya Zemlya archipelago, an area known for its rich bird cliffs and large populations of walrus and polar bears. The Russian Arctic consists of 15 million hectares, including the two major archipelagos Novaya Zemlya and Franz Josef Land. The latter is situated about 540 miles from the North Pole and is a convenient and popular stop for cruise liners (http://barentsobserver.com/en/sections/politics/russian-arctic-national-park-novaya-zemlya).

\section{LEGAL REGULATIONS AND POLICY AS A CONSEQUENCE OF PARTICULAR POLITICAL SITUATION OF ARCTIC SECTORS}

Decisions regarding sovereign powers and jurisdictional boundaries determine the terms and conditions for allowable uses of Arctic resources. Alteration of wildlife, management practices and jurisdictional boundaries will directly impact tourism activities. (Snyder, 2007).

One of the most successful management techniques for conserving Arctic resources and directly influencing lawful visitor behaviour is guide licensing. Licensing requirements vary considerably among Arctic jurisdictions and responsible resource agencies, but fundamental general requirements include: proven knowledge of specific locations, technical skills, safe and efficient recreation delivery systems, waste removal, emergency response systems, and detailed reporting of activities and observations. Arctic guide licensing and the issuance of special use permits have proven to be effective polar tourism management techniques (http://www.grida.no/publications/tourism-polar/page/1422.aspx).

The eight Arctic nations have enacted and enforce numerous laws and regulations governing marine operations and pollution. Based on international regulations, the national laws provide a framework to protect the Arctic environment, promote human safety and provide for a coordinated response to marine incidents, as well as enabling 
cooperation among the Arctic states. National attempts to regulate marine tourism extend from exceedingly stringent controls to considerably more flexible management techniques (Snyder, 2007).

About 40,000 tourists visit Svalbard each year, and a comprehensive set of regulations was recently developed to protect the wilderness there from adverse impacts of tourism (http://www.sysselmannen.svalbard.no/travel_en.htm). There is a heavy cruise ship traffic in and around of Svalbard archipelago, particularly in the capital city Longyearbyen (photo. 3).

Norway's government, for example, plans to significantly restrict cruise ship traffic around the Arctic archipelago of Svalbard and prohibit the use of heavy fuel oil. The new rules will limit to 200 the number of passengers allowed on board each ship that enters nature preserves on East Svalbard, and those tourists who are allowed entry are paying a special environmental tax. All tourist operators on Svalbard must comply with national and international laws and regulations, as well as local jurisdictions. Cruise operators operating on Svalbard have to be familiar with rules and regulations that apply to the group of islands. First of all the Svalbard Environmental Protection Act is important (out to 12 nautical miles from the coast), since it regulates many of the activities that are part of the cruise operators' portfolio. The act is a collection of updated environmental legislation for Svalbard (Jørgensen, 2013).

The Ministry of Justice of Norway has issued a numbers of regulations that are also of relevance to cruise operators. Examples of such regulations are "Regulations relating to tourism and other travel in Svalbard", "Regulations relating to environmentally hazardous substances, waste and waste water and waste management fees in Svalbard", "Regulations relating to off-road motor traffic and the use of aircraft for tourism purposes on Svalbard", "Regulations relating to camping activities in Svalbard",

Photo 3. Example of cruise ship traffic in Longyearbyen, Svalbard

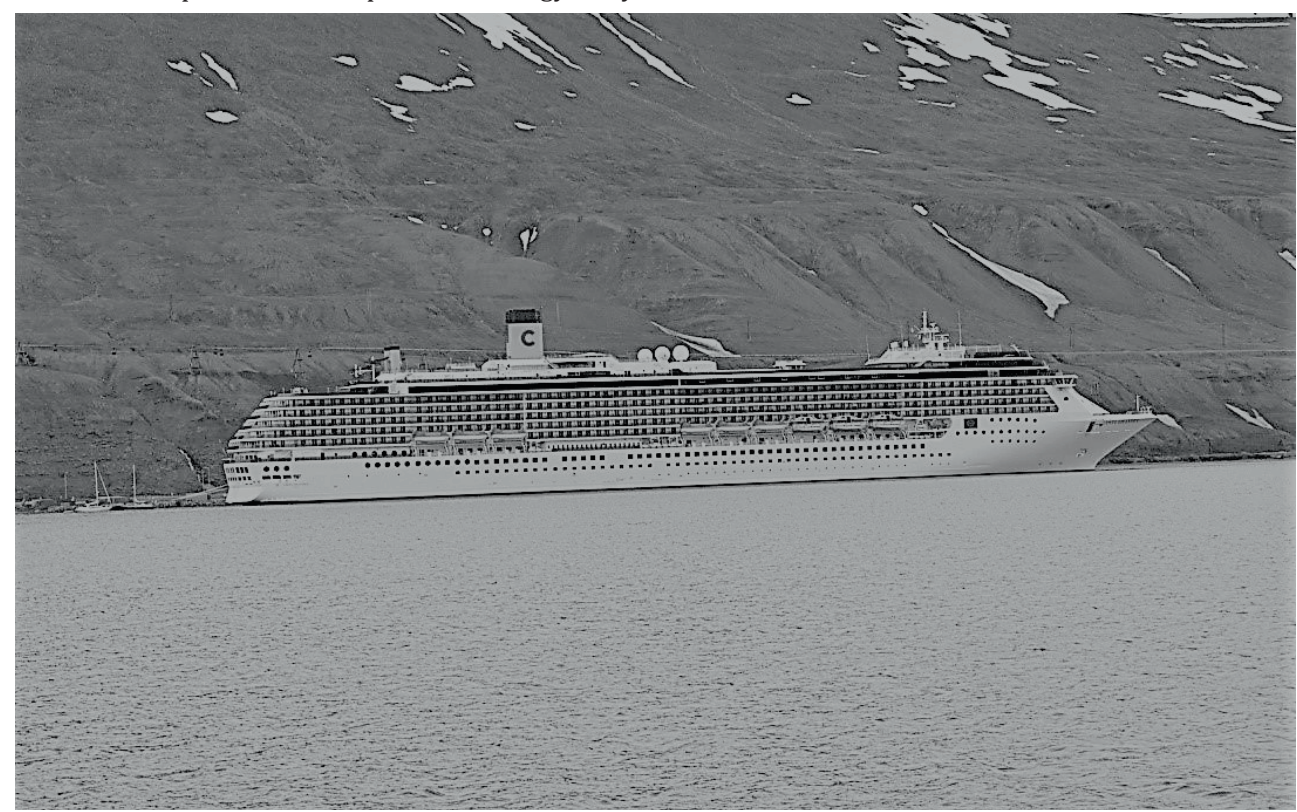

Photo: P. Dolnicki 
"Regulations relating to harvesting of the fauna on Svalbard", and "Regulations relating to environmental impact assessment and delimitation of the land-use planning areas in Svalbard". The Regulations apply to Svalbard's land territory and sea territory to the limit of the territorial waters. Due to these regulations all visitors in Svalbard that plan to visit areas outside the permanent settlements must notify the Governor of Svalbard or a person authorized by the Governor. All ships that travel around Svalbard must report their positions to the Norwegian Coastal Administration when they enter or leave the Svalbard area (Evenset, Christensen, 2011).

Nowadays tourism in Canadian Arctic is regulated on the national law level and there is a lack of effective international legal regulation. This lack of legal rules entails negative risk of the tourism business in the Arctic territory like dealing with hunting permissions in Alaska and Canada (Duhaime et al., 1997).

\section{WEATHER PREFERENCES OF TOURISTS IN THE ARCTIC}

Climate understood as weather is one of the important factors influencing tourism attractiveness of many areas. It has been assumed that global climate change may lead to a shift of tourism demand to higher latitudes, creating additional opportunities for tourism in northern regions (Jacobsen et al., 2011). The ideal climate for tourism should provide basic levels of comfort, enjoyment, and safety (Gómez-Martín, 2006).

In the research of Jacobsen (Jacobsen et al., 2011) there is an example of the interview with 100 respondents, 50 male and 50 female from different countries of various tourism activities, e.g.: sightseeing, guided excursion with boat/ship, outdoor recreation, visit to friends/relatives. The number of $55 \%$ of the respondents had researched the weather/climate conditions for their destination(s) before deciding to go on their trip. There was estimated general description of weather (e.g. very poor, fairly poor, neither bad nor good, fairly good, very good) and weather was compared to expectations (worse than expected, 2, 3, 4, better than expected). 80\% of visitors disagreed with the survey statement "I would not like to return to this area because of the bad weather conditions". Results indicate that tourists to Arctic destinations have a fairly high tolerance for what would regularly be considered unfavourable weather conditions for a summer holiday tour. Looking first at the totals, the main finding is that a clear sky is generally preferred by $87 \%$ of the tourists. In Svalbard, $20 \%$ of the tourists would actually prefer the weather to be rather cool, $70 \%$ would not care, and only $10 \%$ would not like it. Tourists to such Arctic regions generally have fairly low expectations (i.e. they expect rather low temperatures, wind, rain, etc.) with respect to destination weather conditions. The overall preference for clear sky (87\%) stands in contrast to some earlier publications emphasizing temperature as the most important weather aspect. Only a minority of $41 \%$ of Svalbard tourists would like it to be rather warm on a possible future visit. The conclusion is that weather should not be considered a major obstacle to tourism in high-latitude destination areas (Jacobsen et al., 2011).

\section{CONCLUSIONS}

Arctic tourism is developing very quickly. Two groups of factors influencing this phenomenon can be distinguished: natural and anthropogenic. Natural factors are mostly 
connected with climate conditions and particularly sea ice cover, what is linked with accessibility. As far as human activity is concerned, we can focus on development of technical possibilities, meaning e.g. infrastructure and means of transport for cruise tourism, but a very important factor is also the creation of new regulations in order to protect wild environment. Basing on analysis of literature and statistical data the following conclusions may be drawn:

- New possibilities of visiting remote places with severe climate conditions (e.g. Arctic region) are opening due to global changes.

- Reduced sea ice cover for longer periods of time is facilitating improved tourist access and extending visitor seasons.

- One of the best examples of rapid development of tourism in the Arctic may be the Northwest Passage, a historical challenge for many sailors, and Russian Arctic tourism development, which shows a combination of economic and environmental conditions.

- Decisions regarding sovereign powers and jurisdictional boundaries determine the terms and conditions for allowable uses of Arctic resources.

- It has been assumed that global climate change may lead to a shift of tourism demand to higher latitudes, creating additional opportunities for tourism in northern regions.

\section{References}

Burkart, A.J., Medlik, S. (1974). Tourism. Past, Present and Future. London: Heinemann.

Bystrowska, M., Dolnicki, P. (2015). The impact of endogenous factors on diversification of tourism space in the Arctic. Current Issues of Tourism Research, 5, 36-44.

Duhaime, G., Rasmussen, R.O., Comtois, R. (1997). Sustainable Development in the North: Local Initiatives vs Megaprojects. Proceedings of the Second Circumpolar Social Science Ph.D. Network Conference, held in Aguanish, Québec, GETIC, Sainte-Foy, Presses de l’Université Laval.

Evenset, A., Christensen, N. (2011). Environmental impacts of expedition cruise traffic around Svalbard. Association of Arctic Expedition Cruise Operators.

Gómez Martín, M.B. (2006). Climate potential and tourist demand in Catalonia (Spain) during the summer season. Climate Research, 32, 75-87.

Intergovernmental Panel on Climate Change (2007). Climate change 2007: synthesis report. Contribution of working groups I, II and III to the fourth assessment report of the Intergovernmental Panel on Climate Change. Core Writing Team. In: R.K. Pachauri, A. Reisinger (Eds.). IPCC, Geneva, Switzerland.

Jacobsen, J., Denstadli, J., Lohmann, M., Førland, E. (2011). Tourist weather preferences in Europe's Arctic. Climate Research, 50, 31-42.

Jørgensen, F. (2013). Regulation of tourism and prevention of accidents CMERA Workshop. Troms $\varnothing, 6-7$ Nov, AECO.

Pagnan, J. (2003). The impact of climate change on Arctic tourism: A preliminary review. World Tourism Organization First International Conference on Climate Change and Tourism. Djerba, Tunisia, 9-11.04.

Panasiuk, A. (2006). Informacja turystyczna. Szczecin: Wydawnictwo Naukowe Uniwersytetu Szczecińskiego.

Przybylak, R. (2002). Changes in seasonal and annual high-frequency air temperature variability in the Arctic from 1951-1990. International Journal of Climatology, 22.

Rosenberg, M. (2007). The Northwest Passage may allow ship travel across Northern Canada, http://geography.about.com/od/specificplacesofinterest/a/northwestpassag.htm

Snyder, J. (2007). Tourism in the Polar Regions. The Sustainability Challenge. UNEP. 
Stewart, E.J., Dawson, J., Howell, S.E.L., Johnston, M.E., Pearce, T., Lemelin, H. (2013). Local-level responses to sea ice change and cruise tourism in Arctic Canada's Northwest Passage. Polar Geography, 36(1-2).

Svalbard Environmental Protection Act, Act of June 15, 2001, No. 79, Norway. (www.sysselmannen.svalbard.no/laws_enviro_en.htm)

Wallace, J. (2006). Taking the Northwest Passage. Experts stress the importance of answering Arctic sovereignty questions sooner rather than later. Canadian Geographic, 3-4.

www.acia.uaf.edu/pages/scientific.html

www.aeco.no

www.biodiversity.ru/coastlearn/tourism

www. barentsobserver.com/en/sections/politics/russian-arctic-national-park-novaya-zemlya www.cbc.ca/news/canada/north/arctic-tourism-heating-up-as-northwest-passage-melts

www.climate.weather.gc.ca

www.commerce.alaska.gov

www.ipcc.ch

www.sysselmannen.svalbard.no/travel

www.world-tourism.org

www.wto.org

Łukasz Gawor, Ph.D., assistant professor, Silesian University of Technology. Research interests: mining sozology, legal regulations regarding reclamation, reclamation and using of post-mining dumping grounds, geotourism. Other interests: high mountain tourism, polar expeditions, running, ski running.

\section{Adres/address:}

Silesian University of Technology

Institute of Applied Geology

ul. Akademicka 2, 44-100 Gliwice, Polska

e-mail: lukasz.gawor@polsl.pl

Piotr Dolnicki, dr nauk o Ziemi, pracownik Zakładu Turystyki i Badań Regionalnych Instytutu Geografii Uniwersytetu Pedagogicznego w Krakowie. Zainteresowania naukowe: geomorfologia, badania polarne, turystyka w obszarach polarnych.

Piotr Dolnicki, Ph.D., Doctor of Earth Sciences, currently employed in the Department of Tourism and Regional Studies at the Pedagogical University of Cracow. Research interests: geomorphology, polar research, tourism in polar regions.

\section{Adres/address:}

Pedagogical University of Cracow

Department of Tourism and Regional Studies

ul. Podchorążych 2, 30-084 Kraków, Polska

e-mail: dolnicki@up.krakow.pl 